\title{
Anti-VEGF with 3-week intervals is effective on anemia in a patient with severe hereditary hemorrhagic telangiectasia
}

\author{
Philip Fodstad • Sinan Dheyauldeen • Marit Rinde • \\ Gregor Bachmann-Harildstad
}

Received: 3 July 2010 /Accepted: 20 August 2010 /Published online: 8 September 2010

(C) The Author(s) 2010. This article is published with open access at Springerlink.com

\section{Dear Editor,}

We report a patient with severe anemia due to hereditary hemorrhagic telangiectasia (HHT) in whom treatment with anti-VEGF showed a substantial effect [1,2].

A 44-year-old patient with known HHT type 1 disease suffered from severe gastrointestinal hemorrhages, pulmonary arteriovenous malformation (AVM), liver AVM, and severe epistaxis. The patient was treated at the center of excellence for HHT at Oslo University Hospital and at Akershus University Hospital, Norway. First spontaneous epistaxis occurred at the age of 20 years. He was carrying the endoglin splice mutation c.817-1G>T in exon 6 . This mutation has not been described in the literature until now. He had a pulmonary AVM, which was embolized when he was 32 years old. The bleedings from the gastrointestinal tract were treated by argon plasma coagulation using combined laparotomy and enteroscopy of the small intestine in June 2003. Later, the gastrointestinal tract was treated by double balloon enteroscopy and altogether ten

\footnotetext{
P. Fodstad $\cdot$ S. Dheyauldeen

Department of Otorhinolaryngology, Head and Neck Surgery, Oslo University Hospital,

0027 Oslo, Norway

G. Bachmann-Harildstad ( $₫)$

Department of Otorhinolaryngology,

Akershus University Hospital and Oslo University,

1474 Nordbyhagen, Norway

e-mail: gregorb@medisin.uio.no

M. Rinde

Department of Hematology, Akershus University Hospital, 1474 Nordbyhagen, Norway
}

telangiectasies in the ventricle and 120 lesions in the small intestine were coagulated in February 2009. The telangiectasies in the nasal mucosa were of Mahoney grade 2-3 and were treated first with pulsed dye laser in 2003, once with super selective embolization in 2006 and later with argon plasma coagulation under general anesthesia approximately three times per year with some effect [3]. Since 2003, he was transfused regularly and received between 4 and $6 \mathrm{U}$ of packed red blood cells every week. His regular medication was tranexamic acid of $1,000 \mathrm{mg}$ twice daily and intravenous iron once per week. He was started on thalidomide $50 \mathrm{mg}$ per day in April 2007. The thalidomide dose was increased gradually to $200 \mathrm{mg}$ per day, and he had some subjective effect; however, he remained dependent on regular packed red cell transfusions as before. After 1 year on thalidomide, he developed peripheral neuropathy, and the medication was first reduced to $150 \mathrm{mg}$ per day and finally stopped in January 2009. From October until December 2009 , treatment with $5 \mathrm{mg} / \mathrm{kg}$ of bevacizumab every second week was given without complications. After the first infusion, he only needed one further unit of packed red cells and the hemoglobin level remained stable around $10 \mathrm{~g} / \mathrm{dl}$ without further transfusions. The intravenous iron infusions were reduced too. He remained stable for 6 weeks after completion of the first course with bevacizumab (Fig. 1). He became transfusion dependent again, and a second course with $5 \mathrm{mg} / \mathrm{kg}$ of bevacizumab was initiated in March 2010. The second course was planned with $5 \mathrm{mg} /$ $\mathrm{kg}$ of bevacizumab every third week. Due to unforeseen circumstances, there was an interval delay of 5 weeks between dose 3 and dose 4 during the second course. The second course initially did show a remarkable effect with a 
Fig. 1 Filled triangles indicate treatment with bevacizumab. The bars indicate treatment with thalidomide. The white line indicates packed red cells (PRC) transfused [units per week]

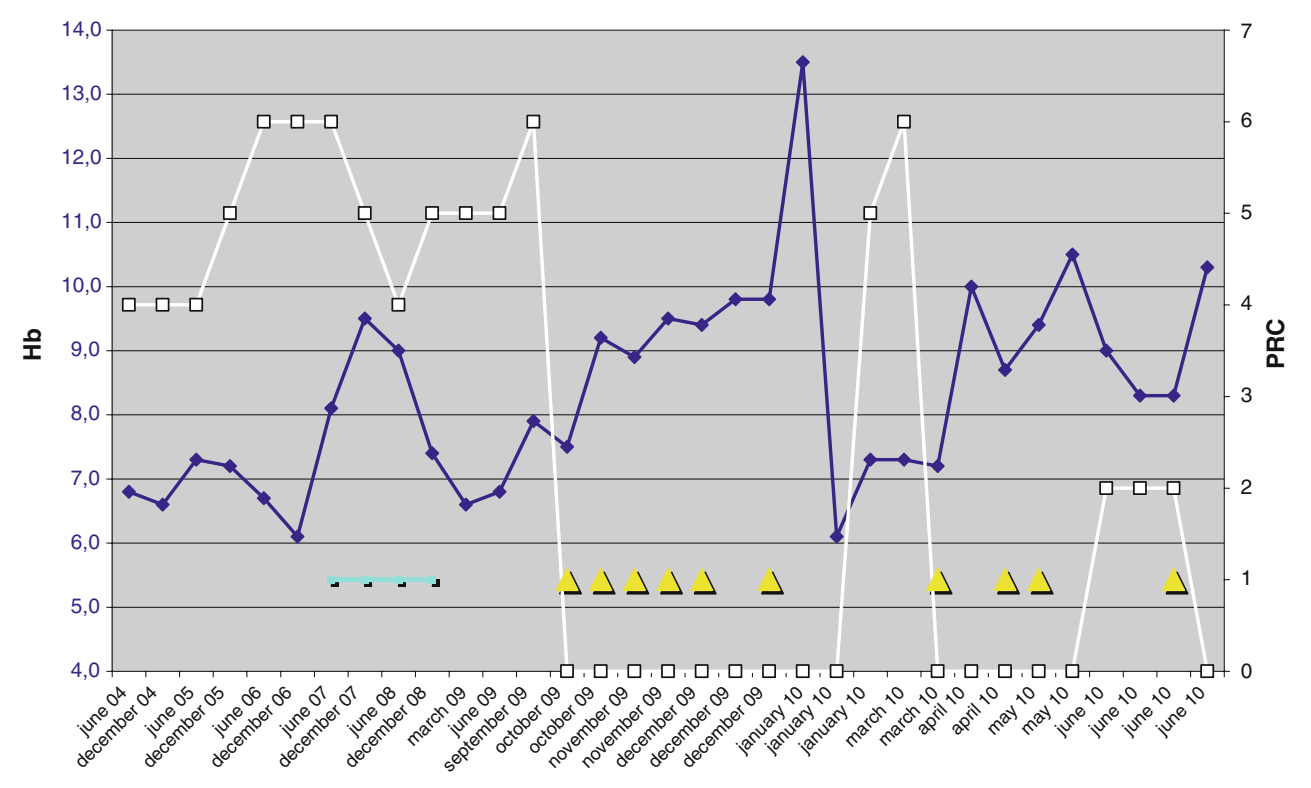

raise in $\mathrm{Hb}$ from 7.3 to $10 \mathrm{~g} / \mathrm{l}$. The effect was reduced after the 5 week interval.

\section{Discussion}

For the treatment of epistaxis in patients with HHT, several therapeutic drugs have been recommended. Tranexamic acid has shown to have some effect; low-dose estrogenprogesterone showed efficacy in an uncontrolled study, and oral tamoxifen was shown to be effective in a randomized placebo-controlled study [4, 5]. From a case report, bevacizumab had a profound effect on a patient with nonbleeding vascular AVMs [6].

\section{Conclusion}

Bevacizumab was effective in this patient with anemia due to severe HHT, also when given in intervals of 3 weeks. In cases with severe visceral AVMs and/or severe intractable and transfusion-dependent epistaxis due to HHT, we recommend a 4.5 -month treatment regime with $5 \mathrm{mg} / \mathrm{kg}$ of bevacizumab, given in 3-week intervals.
Open Access This article is distributed under the terms of the Creative Commons Attribution Noncommercial License which permits any noncommercial use, distribution, and reproduction in any medium, provided the original author(s) and source are credited.

\section{References}

1. Flieger D, Hainke S, Fischbach W (2006) Dramatic improvement in hereditary hemorrhagic telangiectasia after treatment with the vascular endothelial growth factor (VEGF) antagonist bevacizumab. Ann Hematol 85(9):631-632

2. Bose P, Holter JL, Selby GB (2009) Bevacizumab in hereditary hemorrhagic telangiectasia. N Engl J Med 360(20):2143-2144

3. Mahoney EJ, Shapshay SM (2006) New classification of nasal vasculature patterns in hereditary hemorrhagic telangiectasia. Am J Rhinol 20(1):87-90

4. Jameson JJ, Cave DR (2004) Hormonal and antihormonal therapy for epistaxis in hereditary hemorrhagic telangiectasia. Laryngoscope 114(4):705-709

5. Yaniv E, Preis M, Hadar T, Shvero J, Haddad M (2009) Antiestrogen therapy for hereditary hemorrhagic telangiectasia: a double-blind placebo-controlled clinical trial. Laryngoscope 119 (2):284-288

6. Mitchell A, Adams LA, Macquillan G, Tibballs J, vanden Driesen R, Delriviere L (2008) Bevacizumab reverses need for liver transplantation in hereditary hemorrhagic telangiectasia. Liver Transpl 14(2):210-213 